\title{
Local Wisdom in Lawas (Poetry) Ponan Party Ceremony Society of Sumbawa Nusa Tenggara Barat
}

\author{
Heni Mawarni, Sarwiji Suwandi, Slamet Supriyadi
}

\author{
Post-graduate ofIndonesian Language Education, University of Sebelas Maret. Surakarta, Indonesia
}

\begin{abstract}
Local wisdom means a good relationship between humans, nature, and the environment in an area that is also influenced by its culture. The globalization phenomenon and modernization nowadays often leaves cultures rapidly forgotten, therefore they need to be preserved, one of them is the Ponan Party Ceremony. Ponan Party Ceremony is an annual tradition carried out by the Sumbawa people of West Nusa Tenggara, which contains many of the local values. This study aims to explore the local wisdom embedded in the lawas (poetry) of Ponan Party Ceremony in Sumbawa. The research method used in this research is descriptive qualitative through literature studies in relation of local wisdom. The results of this research show that the lawas (poetry) of Ponan Party Ceremony are as following: love the environment, religious values, social values, tradition, and culture. Local wisdom needs to be preserved in order to keep up and balance with modern times.
\end{abstract}

Keywords- culture, Sumbawa Village, Ponan, lawas (poetry).

\section{INTRODUCTION}

Nature, people, and the environment have a close relationship. In the past, humans understood the language of nature. Traditional communities collect them into a system of knowledge, which would then be used to interact with others. A language-oriented system of knowledge in a certain region is called local wisdom. Indonesia is known to be very rich in traditional languages and cultures. Bahasa Indonesia is used as the unification language of the diverse regions. Besides that, Bahas a Indonesia also developed as the official language of the country and the language of knowledge and technology. One of the traditional languages that continues to grow is the language of Sumbawa, called 'Samawa'.

Samawa is a language used to communicate and interact with local residents who are used collectively (Zulkarnain, 2015). The development of technology as a result of globalization has decreased the fondness and pride of using traditional languages, including in
Sumbawa. Therefore, the Sumbawa language needs to taken into consideration, as to preserve it fromextinction. There are some ways that can be done to preserve it, including introducing the Sumbawa culture, for example maen jaran (horse race), barapan kebo (buffalo race), Ponan Party Ceremonies, wedding processions, and so on. Every culture in the Sumbawa community has local wisdom that needs to be maintained.

\section{THEORIES OF LOCAL WISDOM}

Local wisdom is the identity or cultural personality of a nation that causes the nation to be able to absorb, even cultivate cultures that originate from the outside / the nation becomes its own character and ability (Wibowo, 2012). These identities and personalities naturally adjust to the views of the local community so that the values do not shift. Local wisdom is one of the means of cultivating one's own culture and defending themselves from unfavorable foreign cultures.

Local wisdom is a perspective on life and knowledge, including various life strategies in the form of activities that society does in order to solve their problems on meeting their needs. In foreign languages, it is often also conceptualized as local wisdom or local genius knowledge (Fajarini, 2016). Various strategies are carried out by the local community to maintain their culture. On the other hand, (Parkes, Peter., Ellen, R. F., \& Bicker, 2005) named it local knowledge (local wisdom). Local knowledge is defined as follows: 1) knowledge that is associated with a place and a series of experiences, and developed by the local community; 2) knowledge obtained through mimicry, imitation and experimenting; 3) daily practical knowledge obtained from trial and error; 4) non-theoretical empirical knowledge; 5) comprehensive and integrated knowledge in the fields of tradition and culture. The same thing was also expressed by (Alfian, 2013), stating that local wisdom is interpreted as a view of life and knowledge as well as a tangible life strategy of activities carried out by local communities in meeting their needs. 
Local wisdom according to (Istiawati, 2018) states that local wisdom is the way people behave and act in response to changes in the physical and cultural environment. A conceptual idea that lives in society grows and develops continuously in the public awareness of the nature related to the sacred life to the profane (the daily, mundane part of life). Local wisdom can be understood as local ideas that are wise, full of good values, embedded and followed by community members.

Local wisdom according to (Ratna, 2011) is a cement binding in the form of an existing culture, so that it is based on existence. Local wisdom can be defined as a culture created by local actors through repetitive processes, through internalization and interpretation of religious and cultural teachings that are socialized in the form of norms and used as guidelines in daily life for the community. Based on the opinions above, it can be concluded that local wisdom is the habit of a group of people that is inherited, full of benign intentions, embedded and followed by members of the society. The forms that they take include customs, culture, language, religious beliefs, rules, and daily practices in life.

\section{FORMS OF LOCAL WISDOM}

The local wisdom is diversity harmony in the form of social practices based on wisdom from culture. Local wisdom in society takes its form in culture (values, norms, ethics, beliefs, customs, customary laws, and special rules). Noble values included in local wisdom are as following: Love of God, love of the universe, responsibility, discipline, independence, honesty, respect, politeness, compassion, confidence, creativity, hard work, persistence, justice, leadership, humility, tolerance, peacefulness, and unity (Haryanto, 2014).

The same thing was stated by (Wahyudi, 2014) local wisdom is an unwritten rule that is a reference for the community that covers all aspects of life, in the form of rules relating to relations between humans, for example in social interactions between individuals and groups, relating to hierarchies in governance and custom, rules of marriage between clans, and karmic order in everyday life. The rules of regulation concern human relations with nature, animals, plants which are more aimed at nature conservation efforts. Regulations concerning human relations with the occult, for example God and supernatural spirits. Local wisdom take in the form of customs, institutions, wise words, proverb (Javanese: parian, paribasan, bebasan and saloka), in local wisdom literature is clearly a language, both oral and written. In society, local wisdom can be found in folklore, singing, sayings, sasanti, advice, slogans, and ancient books that are inherent in everyday behaviors (Ratna, 2011). This local wisdom will manifest into a traditional culture and reflected in the values that apply in certain community groups.

Local wisdom is also expressed in the form of wise words (philosophy) including advice, proverbs, poetry, folklore (oral stories), and so on; social and moral rules, principles, norms and rules that become social systems; rites, ceremonial or traditional and ritual ceremonies; and habits that are seen in everyday behavior in social interactions (Haryanto, 2014).

Sumbawa is one of the places that are still tenacious when it comes to the values of local wisdom. The culture of West Nusa Tenggara must be preserved as the wealth and pride of the region (Irfan \& Suryani, 2017). The culture that is owned by a nation is a way of life of people who inhabit an area in groups, assumed not to belong to humans, but to function as a sign or identity of the group itself (Nnamani, 2019). There are many more regions that utilize local wisdom to support their economy, such as the Balinese who are famous for their art and are still attached to their religious rituals and Garut which is famous for its dodol. This is the form of local wisdom in our culture.

The people of Sumbawa is an example of implementations of local wisdom with their annual rituals, done in order to carry out orders of God's with praying, giving alms, making pilgrimages, being in harmony with others and studying the teachings about His commands, practicing and obeying carefully all the teachings of spirituality. Besides that, Sumbawa also saves a lot of local wisdom in its community. One of the customs that is carried out by the people of Sumbawa is the Ponan Party Ceremony.

The Ponan Party Ceremony is one of Sumbawa people's tradition that is sanctified, due to the myths that it contains. The ceremony takes place in rice fields. The sweets eaten in the ceremony are wrapped in leaves commonly used to wrap food, such as banana and coconut leaves. The Sumbawa people believe that those wrappers can make residents' rice plants devoid of pests and their crops will be abundant. The execution of Ponan Party Ceremony is done in Poto Village. Not only does it teach spirituality and beliefs, it also shapes the people to be affectionate, loving, compassionate, faithful, and aware. Every society in a region is unique in expressing itself. This form of expression can be done in the form of architecture, art, and literature (Fokkema, 1998; Masindan, 1986; Pudentia, 2015), such as poetry, prose, and drama. Poetry brings many oral messages conveyed by musical sounds, rhythms, and techniques, can spontaneously attract the attention of the audience (Hamdan, 2019).

Likewise, the Sumbawa people also have the uniqueness to express themselves, such as through Sakeco, Panan, Tutir, and lawas (poetry). The people of 
Samawa inhabiting the Sumbawa Island have various forms of art (Musbiawan, 2016) and folk poetry inherited continuosly from the ancestors. The Sumbawa is land is a region in Indonesia and the biggest island in the Province of Nusa Tenggara Barat. This island is inhabited by two big ethnicities, the Mbojo people on east and the Samawa people on west (Lalu Mantja, 2011). The Ponan Party Ceremony is filled with exhibition and performances of culture and literary arts, both oral and written, one of the oral form is lawas (folk poetry).

\section{DEFINITION OF LAWAS (FOLK POETRY)}

The word lawas (poetry) in Kamus Besar Bahasa Indonesia means 'wide, spacious'. Associated with the word 'ber-lawas' in the Samawa people ('balawas'), which shows about lawas (poetry), it would mean "having a spacious, wide heart." In other words, lawas (poetry) is the human creation that created and expressed by language; by writing or oral that risen the happiness and sadness in the human soul (human creation that is born and expressed in languages, both oral and written which creates a sense of beauty and renewal in the depths of the human soul) (Government, 1997:12).

Lawas (poetry) was originally rooted in the Sumbawa language and couldn't be detected when it started to be present amongst the people. However, its presence in the life of the Samawa community began as a means of expressing the inner human being filled with feelings of emotion, sadness and disarray, perhaps caused by disasters or danger in life. Whether to overcome or entertain, feelings are expressed in the form of words. These sayings seemed to be a force in the ceremony to drive away the elements that cause the sense of danger (Sukiman, 2018).

Lawas (poetry) is one of the oral arts that exists and developed in the Samawa community in the form of traditional poetry. The word lawas (poetry) is basically oral poetry that has been attached to the people of Sumbawa, and a legacy that was developed orally both in cities and in the countryside (Fajarini, 2016)

Hamim (2010) lawas, as folk poetry in Sumbawa, is said to be a human creation that was born and expressed in oral and written language that gave birth to a sense of beauty and necessity in the depths of the human soul (Made Suyasa, 2001). Lawas (poetry) is literature that is used to express the atmosphere and content of the heart in order to convey them to other people (connoisseurs or listeners) or reader (Juanda, 2016). Lawas (poetry) sung with temung (rhythm) is called balawas. The balawas event is very popular with the Sumbawa people, and it can take the forms of sakeco, melangko, badede, ngumang, or saketa in a performance ceremony. Lawas is poetry in the language of Sumbawa, with anonimity in its creation, whether oral or written, to express or convey one's heart contents in various events (Sumbawa Tourism Agency, 1997: 9).

Lawas Samawa can take the form of prose, stories, history, and also in the form of poetry called lawas, and among the Sumbawa ethnic community it is always used in various activities, for example in mutual cooperation activities, marriages, cultural events, and barapan kebo (buffalo race) so that the old (poetry) still continues to grow today. Lawas (poetry) known from the past so that it belongs to the community together, developed from generation to generation by oral means in various activities involving many people, by remembering or memorizing them. Lawas (folk poetry) is still developing today as Sumbawa's oral literature. Sumbawa oral literature is delivered by telling it or being delivered by word of mouth (regeneration) (Amin, 2012).

Lawas (folk poetry) are verses/runes that are delivered as forms of conveying love, sadness, critic, advice, and so on (Sukiman, 2018). Furthermore, lawas (poetry) is a poem consisting of three lines, provided that each line is intertwined, three strands and each row consists of eight syllables. Lawas (folk poetry) contains a deep understanding, out of a subtle feeling, inviting listeners to examine and think seriously, for example the complaints of ordinary people against state officials who live in luxury among citizens who lack housing, clothing, and food. From some of the opinions above, it can be concluded that Lawas (folk poetry) is an oral literature (folk poetry) of the Sumbawa people. Until now, it is still developing and used to express the contents of the heart to the interlocutors delivered at certain times both individually and in groups.

In particular, lawas has certain characteristics that are rigid and has been converted by the Sumbawa people. The characteristics are as follows: (i) each verse consists of three lines; (ii) each row consists of eight syllables; (iii) there is no repetition of the word meaning the same in one verse; (iv) between the three lines in one strophe is a whole unit. For example, (i) each verse consists of three lines, /lamin sia dunung notang/sowe santek banga bintang/pang bulan batemung matal. Example (ii) each row consists of eight syllables, /la-minsi-a-du-nung-no-tang/ (8 syllables). Example (iii) there is no repetition of the word meaning the same in one verse, Ipang bulan batemung mata/. In lawas (folk poetry) many contain values and mandates to listeners and contain the value of local wisdom. Based on what has been discussion above, the purpose of this study is to reveal the local wisdom contained in lawas (folk poetry) Ponan Party Ceremony in the Sumbawa community of West Nusa Tenggara.

\section{RESEARCH METHODS}

This research uses desciptive qualitative approach. Moleong (2010) states that qualitative research 
is research that intends to understand the phenomenon of what is experienced by the subject of research such as behavior, perception, motivation, action, holistically and by means of descriptions in the form of words and language, in a specific natural context and by utilizing various scientific methods. Data collection in this study is using the method of observation, listening, interviewing, and document analysis. According to Lofland in. Moleong (2010) the main data sources in qualitative research are words, actions, and document data. The data sources in this study are in the form of documents and the people of Sumbawa Regency, West Nusa Tenggara.

\section{RESULTS AND DISCUSSION}

Based on data collection and data analysis, the results of this study are as follows;

\subsection{Love the Environment}

Environment is a place where human life processes take place. Nasution (1996) states that the environment is broadly divided into two, including; (a) physical environment is defined as something that is outside of someone who is not related to humans, such as nature, weather, climate, buildings and (b) non-physical environment is an environment that is directly related to humans, such as daily interaction. The Ponan Party Ceremony also provides lessons for us about managing nature and the surrounding environment in order to stay sustainable. Quoting lawas (poetry) Sumbawa;

Data 1 Kle tu sablong desa,

na sarusak tani tana,

sanuman nanta tu mudi

\section{Translate;}

Although we build villages,

Don't damage nature and the environment,

There are still the posterity

Data 1 lawas (poetry) above reveals that we must love and preserve the environment around us, by managing, maintaining, and caring for it. Preserve what already exists and not destroy it, because in the future there will still be our grandchildren who will occupy where we live.

\section{Data 2 Karoro sesa sadeka}

Karampo kokat kabala

Kareng ola pang panungkas

Translate;

Leftovers from the charity

Picked up together

Then placed in the paddy field
Data 3 Buwa olo pang panungkas

Leng dadimo medo bura

Subur balong mole pade

\section{Translate;}

Why are they placed in plots

Because it can clear up pests

So that the rice will always be fertile

Data 2 and 3 explain about maintaining environmental cleanliness during the ceremony. Food and cakes served in leaf wrappers (using banana leaves, coconut leaves, or bamboo leaves) should not be thrown away after they are eaten. When the ceremony is over, all the participants of the event must collect their leftovers to maintain environmental cleanliness, so for those who take part in the Ponan Party Ceremony, the wrapping leaves will be thrown in the fields or around the rice fields in hopes of repelling pests and diseases. It is also believed that this kind of thing is a form of maintaining cleanliness and balance between nature and rice plants.

\subsection{Religious Values}

Religious value is an attitude or behavior based on rules or rules of religion. Religious values reflect the human attitude or behavior towards God. Zakiyah Q. Y \& Rusdiana (2014) stated that religious values are values that are to be instilled through the process of Islamic education, which is about devotion to God (Allah SWT) and the values that govern human relations. The lawas (poetry) containing religious values in the Ponan Party Ceremony are as follows;

\section{Data 4 Tusamula mo tutir ta} Kewa singin Nene kita

Anung sopo manang mes

\section{Translate;}

Let's start the poem,

By the name of our god, Only Allah SWT.

Data 5 Kusamula ke bismillah

Kusasuda ke wassalam

Nan ke salamat parana

\section{Translate}

Starting with bismillah, Ending with greetings

So that we will be safe

Data 6 Baliukmo silapangkan Ode-rea, loka-tua Rembang seda sikir-tahlil 
Translate;

Sitting together, mingling with each other

Whether small, young, or old

Together saying dhikr and tahlil

Data 7 Sikir-tahlil-basadeka

Runtung tin pang untir ponan

Waya suda tanam pade

\section{Translate;}

Dhikr, tahlil, and charity,

Every year at Ponan's party,

After planting the rice.

The lawas (poetry) data above is an explanation of the ponan party held at Ponan hill, carried out by the hamlets of Poto, Lengas and Malili in Moyo Hilir Subdistrict, Sumbawa, formerly from one cluster, the Bekat Village held in Penang Hill, conducted by the hamlet Poto, Lengas, and Malili in Moyo Hilir Subdistrict, Sumbawa, previously from one cluster, Bekat Village.

The series of Ponan ritual processes starts from the preparation of the community to execute the Ponan celebration. data 4 and 5 explain that as Muslims who believe in Allah, His name should always be remembered and mentioned in every moment by starting something by saying "Bismillah" and closing it with greetings, so that we are safe in His protections. In data 6 and 7, the mingling of people from various sizes and ages to recite the dhikr, tahlil, and giving charity are signs of our gratitude to Allah SWT for all His blessings that are always given to us.

\subsection{Social Value}

Social value is a value that is considered good in humans. Nwaubani \& Okafor, (2015) Social value is a value that is considered good in humans. Social value is a value that must be instilled in humans, as early as elementary school level, in order to be able to become citizens with moral values in community life to live peacefully. Lawas (poetry) which contain social values are as follows;

\section{Data 8 Adamo sopo katokal}

Pang tengatan onrong rea

Desa poto-Moyo Hilir

Translate;

We are in one place,

In the midst of rice fields,

Poto, Moyo, Hilir Villages
Data 9 Dusun Lengas Desa Poto

nansi Dusun Bekat Beru

Asal kalis Bekat Loka

Translate;

Lengas Hamlet, Poto Village,

That is the Bekan Beru Hamlet,

Originally Bekat Loka

Data 10 Pang masa Dam Batu Bulan

Manasi kakurang ujan

Tusatentu mole pade

Translate;

During the times of Batu Bulan dam,

Even though rainfall is lacking,

Determining when to farm.

Data 11 Nanok puin kayu jawa

Pang baserip tusiara

Ramemo tokal baliuk

Translate;

Under the kawa wood tree,

People who come to take shelter,

Sit together.

Data 12 Rungan rame boat sia

Bagentar tana Samawa

Bato mo nyata ku gita

\section{Translate;}

Your party is festive, Sir,

Rocking the Samawa land,

And now it is real.

Data 8 untill data 12 describes the place and ponan ceremony procession. The ritual starts with members of the village gathering in the village gate before walking together to the Ponan Hill. They walk hand in hand, carrying the food and drinks that have been prepared beforehand for the participants of the ceremony. After they arrive, they have prayers together, lead by the headman. They pray for prosperity to befall upon the three villages, for God to give them crops in abundance.

In addition, this occasion also serves for residents to forgive each other for anything that might offend anyone during the ceremony, whether there were errors in the distribution or mistakes during the irrigation process for examples. They ask for forgiveness and forgive each other so there would be no grudges kept and burdens held in the heart, which would damage the unity and brotherhood. According the Sumbawa people, there is a strong relation between crops yield and relationships among people in Ponan party ceremony. If their 
relationships are healthy, so will the crops, and vice versa. They believe that Allah SWT will bring prosperity to people who maintain good relationships with others. Values that can be taken from the lawas above are respect for each other, helping each other, unity, compassion, and believing in each other.

\subsection{Value of Tradition or Culture}

According to Nababan (1988), culture is perceived as a system of communication with human behavior, and language is one part or subsystem of culture. As a subsystem of the culture, linguistic behaviors also follow the norms of its parent culture. This linguistic behavior system is called 'language procedure' (linguistic etiquette). Altman dan Chemers (1984) states that there are five important factors regarding intercultural and environmental relations; 1) the natural environment, includes temperature, rainfall, geography, flora and fauna; 2) environmental orientation and outlook on life, includes cosmology, religion, values and norms; 3) environmental cognition, includes perception, trust, and judgment; 4) environmental behavior, includes privacy, personal space, territory and density; 5) the environment as the final product in the form of a built environment, houses, agriculture, and cities. These five factors are interrelated with each other, this shows the relationship between the culture and the environment that is built, to better understand the culture of the built environment. The cultural value of the Ponan ceremony is found in lawas (poetry) below;

\section{Data 13 Tepung kalis loto pade \\ Buras, lepat ke petikal \\ Topat srapat. Tepung batas}

\section{Translate;}

Snacks from rice,

Buras, lepat, and petikal,

Topat and wet snacks

\section{Data 14 Tepung kiping, Onde-onde \\ Jadi Kebo, Ai Aning \\ Sadeka terap ke Timung}

\author{
Translate; \\ Tepung kiping, onde-onde, \\ Buffalo milk, honey, \\ Charities with timung.
}

Mentioned in data 13 and 14 are typical Sumbawa snacks or cakes served during the Banquet Ceremony. This snack wrap is from banana leaves, coconut leaves, bamboo leaves, and should not be disposed of carelessly after being eaten. For the Ponan indigenous people, the leaves must be thrown in the fields or around the fields, because they are believed to be able to repel pests and diseases.

The next step is to prepare snacks that are prominent to the ceremony, which are buras, lepat, petikal, Topat, Tepung batas, Tepung kiping, Onde-onde, Jadi Kebo, Ai Aning dan Timung. These are all made from rice, not fried or cooked using oil, and only cooked with firewood. The Sumbawa community believe that if the food is cooked with oil, then it will be less tasty. This process is intended to be a form of gratitude and local wisdom in maintaining cultural preservation, because cooking with firewood was what their ancestors did. The people believe that the smoke coming from the firewood are a form of prayer that will reach the sky, and will evaporate to become clouds that will bless the land with rain so that their farms will not be dried out. The values that can be taken from the above lawas is the meaningful traditions of serving cakes in the Ponan Party Ceremony.

\section{CONCLUSIONS AND SUGGESTIONS}

Based on the results of data analysis and discussion, conclusions and suggestions in this study are as follows;

\subsection{Conclusions}

Based on the results of the research and analysis of the data above, it can be concluded that culture or tradition in an area is an identity held by the people who inhabit the area. One of the annual traditions carried out by the community is the Ponan Party Ceremony that has been attached to the Sumbawa people of West Nusa Tenggara, in this tradition the community in addition to performing the Ponan Party Ceremony also displays various kinds of Sumbawa arts and culture that are familiar to the local community namely lawas (poetry). Lawas (poetry) are always displayed in every cultural performance of the Sumbawa community because in addition to having an interesting rhymes, lawas (poetry) also brings messages and speaks the values of local wisdom in it. For example, (a) loving the environment, as human beings who depend on resources of the earth, we must love nature by sustaining it, (b) religious values, as religious people, human beings must uphold the religion they have embraced by giving thanks for everything that has been given by God, and (c) social values, as social beings, we have to maintain our relationship not only with our creator and the environment, but also with other humans whom we socialize with, and (d) the values of tradition and culture, by establishing good relationships with others, culture and traditions are born, and they hold meaningful values which we have to uphold and preserve. 


\subsection{Suggestions}

The author hopes that the results of this study can be used as a reference and reference for further research on lawas (poetry). The author's suggestion for further research is to examine more about lawas (poetry) and folklore in the Sumbawa community.

\section{REFERENCES}

[1] Alfian, M. (2013). Potensi kearifan Lokal Dalam Pembentukan Jati Diri dan karakter Bangsa. The 5th International Conference on Indonesian Studies: "Ethnicity and Globalization," 424-435. Retrieved from https://icssis.files.wordpress.com/2013/09/201301-33.pdf

[2] Altman dan Chemers. (1984). Culture and Environment. Brook/Cole PublishingCompany. California : Brook/Cole Publishing Company.

[3] Amin, U. (2012). Kamus Bahasa Sumbawa-Indonesia. Yogyakarta : CV. Arti bumIntaran.

[4] Fajarini, U. (2016). Peranan Kearifan Lokal Dalam Pendidikan Karakter. SOSIO DIDAKTIKA: Social Science Education Journal, 1 (2). https://doi.org/10.15408/sd.v1i2.1225

[5] Fokkema, D. W. (1998). Teori Sastra Abad Kedua Puluh. PT Gramedia Pustakan Utama. Jakarta.

[6] Government, Tourism Service of Sumbawa. (1997). The Regional Art of The Principal Tourism Object of Sumbawa. Sumbawa.

[7] Hamdan, M. A. (2019). Jazz Aesthetics Speak Loud in Allen Ginsberg's Howl : A Thematic Cultural Sketch, 4(1), 81-88.

[8] Hamim, M. (2010). Lawas Sawama Dulu dan Kini. Mataram: Mataram.

[9] Haryanto, J. T. (2014). Kearifan Lokal Pendukung Kerukunan Beragama pada Komunitas Tengger Malang Jatim. Jurnal Analisa, 21(02), 201-213.

[10] Irfan, M., \& Suryani, A. (2017). Local Wisdom Based Tourist Village Organization in Lombok Tourist Area. International Journal of English Literature and Social Sciences, 2(5), 73-82. https ://doi.org/10.24001/ijels.2.5.10

[11] Istiawati, N. F. (2018). Pendidikan Karakter Berbasis Nilai-Nilai Kearifan Lokal Adat Ammatoa Dalam Menumbuhkan Karakter Konservasi. CENDEKIA: Journal of Education and Teaching, 10(1), 1-18. https://doi.org/10.30957/cendekia.v10i1.78

[12] Juanda. (2016). Kesadaran Keberagaman dalam Sastra Samawa. Fakultas Keguruan dan Ilmu Pendidikan Universitas Samawa. Sumbawa: Fakultas Keguruan dan Ilmu Pendidikan Universitas Samawa.

[13] Mantja, Lalu. (2011). Sumbawa Pada Masa Dulu : Sumbawa : CV. Samratulangi, NTB.

[14] Suyasa, Made (2001). Wacana Seni Belawas dalam Masyarakat Etnis Samawa. Denpasar: Universitas Udayana.

[15] Masindan, D. (1986). Sastra lisan Melayu Langkat.
Jakarta : Pusat Pembinaan dan Pengembangan Bahas a Departemen Pendidikan dan Kebudayaan.

[16] Moleong, L. J. (2010). Metodologi Penelitian Kualitatif. Remaja Rosda Karya. Bandung: Remaja Rosda Karya.

[17] Musbiawan, H.(2016). Ragam Alat Musik Tradisional Sumbawa. Kantor Arsip dan Perpustakaan Daerah Sumbawa. Sumbawa: Kantor Arsip dan Perpustakaan Daerah Sumbawa.

[18] Nababan, P. . D. P. (1988). Sosiolinguistik Suatu Pengantar. Gramedia. Jakarta: Gramedia.

[19] Nasution, H. (1996). Islam Rasional: Pemikiran dan Gagasan. Bandung: Mizan. Retrieved from http://repository.upi.edu/1360/1/s_d5451_0604180_cha pter1.pdf

[21] Nnamani, D. S. N. (2019). The Importance of Music in the Cultural Policy of Nigeria: A Focus on Selected Igbo Folk Songs. International Journal of English Literature and Social Sciences, 4(1), 1-11. https ://doi.org/10.22161/ijels .4.1.1

[22] Nwaubani, O. O., \& Okafor, O. S. (2015). Assessing the Moral Relevance of Peace Education Contents in the Basic Education Social Studies Curricula for Effective Citizenship Participation in Nigeria. Journal of Education and Practice, 6(13), 79-87. Retrieved from https://search-proquestcom.proxy.library.uu.nl/docview/1773220417?accounti $\mathrm{d}=14772$

[23] Parkes, Peter., Ellen, R. F., \& Bicker, A. (2005). Indigeneous Environmental Knowledge and Its Transformations. Singapore : Publishers :

[24] Pudentia. (2015). Metodologi Kajian Tradisi Lisan: Yayasan Pustaka Obor Indonesia. Jakarta: Yayasan Pustaka Obor Indonesia.

[25] Ratna, N. K. (2011). Antropologi Sastra: Peranan Unsur-Unsur Kebudayaan dalam Proses Kreatif. Yogyakarta: Pustaka Pelajar.

[26] Sukiman. (2018). PEMANFAATAN KESENIAN SAKECO ETNIS SAMAWA. Educatio, 12(1), 1-10.

[27] Wahyudi, A. (2014). Pesona Kearifan Jawa. Yogyakarta: Dipta.

[28] Wibowo, A. (2012). Pendidikan Karakter: Strategi Membangun Karakter Bangsa Berperadaban. Экономика Региона, 2012.

[29] Zakiyah Q. Y \& Rusdiana. (2014). Pendidikan Nilai: Kajian Teori dan Praktik di Sekolah. Bandung: CV Pustaka Setia.

[30] Zulkarnain, A. (2015). Tradisi dan Adat Istiadat Samawa. Biomass Chem Eng. Yogyakarta: Ombak. 